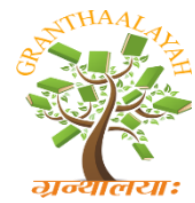

INTERNATIONAL JOURNAL OF RESEARCH GRANTHAALAYAH A knowledge Repository

Social

\title{
EMOTIONAL INTELLIGENCE AND IT IMPACT ON ACADEMIC ACHIEVEMENT IN ZOOLOGY AMONG HIGHER SECONDARY STUDENTS
}

\author{
T.Sivakalai ${ }^{1}$, Mrs.Nalinilatha ${ }^{2}$ \\ ${ }^{1}$ M.Ed Scholar, RVS College of Education, Sulur, India \\ ${ }^{2}$ M.Sc.,M.Ed.,M. Phil.,NET, SLET, Assistant professor in Education, RVS College of \\ Education, Sulur, India
}

DOI: https://doi.org/10.29121/granthaalayah.v5.i5(SE).2017.1971

\begin{abstract}
Emotional intelligence is a type of intelligence that involves the ability to monitor, understand one's own and others emotions, to discriminate among them and to use the information to guide one's thinking and actions. It is the capacity to process emotional information accurately and efficiently taking into account information relevant to the recognition, construction and regulation of emotion in oneself and others. The study aimed to examine the Emotional intelligence and it impact on academic achievement in zoology among higher secondary students. The investigator adopted survey method to study the Emotional intelligence and it impact on academic achievement in zoology among higher secondary students. For this study a sample of 300 higher secondary students from five Govt and Private schools which are situated in and around Coimbatore district in Tamil Nadu were selected by the investigator using simple random sampling technique. The findings reveal that is inferred that there is a difference in the level of emotional intelligence and achievement in zoology among higher secondary students.
\end{abstract}

Keywords: Emotional Intelligence; Capacity; Zoology; Academic Achievements.

Cite This Article: T.Sivakalai, and Mrs.Nalinilatha. (2017). "EMOTIONAL INTELLIGENCE AND IT IMPACT ON ACADEMIC ACHIEVEMENT IN ZOOLOGY AMONG HIGHER SECONDARY STUDENTS." International Journal of Research - Granthaalayah, 5(5)SE, 73-77. https://doi.org/10.29121/granthaalayah.v5.i5(SE).2017.1971.

\section{Introduction}

Emotional intelligence is the capacity of an individual to define his own emotions. It refers to an array of non-cognitive skills, capabilities and competencies that influence a person's ability to cope with environmental demands and pressures (cited in Dulewicz and Higgs, 2000). It is the ability to sense, understand and effectively apply the power and acumen of emotions as a source of human energy, information, connection and influence. Emotional intelligence is a different 
way of being smart. It includes knowing what one ${ }^{e e}$ feelings are and using the feelings to make good decisions in life. It se $^{\text {ec }}$ being able to manage distressing moods, well moods and control impulse. Ite ${ }^{e}$ s being motivated and remaining hopeful and optimistic when one has setbacks in working towards goals. It"s empathy - knowing what the people around one are feeling. It ${ }^{\text {ee }} \mathrm{s}$ a social skill of getting along well with other people, managing emotions in relationships, being able to persuade or lead others (O'Neil, 1996). Emotional intelligence is a "type of social intelligence that involves the ability to monitor one's own and others' emotions, to discriminate among them, and to use the information to guide one's thinking and actions" (Mayer \& Salovey, 1993). Daniel Goleman (1998) defines emotional intelligence as "a matter of aptitude, a capacity that profoundly affects all other abilities, either facilitating or interfering, with them". He further says that "emotional intelligence refers to the capacity for recognizing our own feelings and those of others, for motivating ourselves, and for managing emotions well in ourselves and our relationship".

\section{Design of the Study}

The investigator adopted survey method to study the Emotional intelligence and it impact on academic achievement in zoology among higher secondary students. For this study a sample of 300 higher secondary students from five Government and Private schools which are situated in and around Coimbatore district in Tamil Nadu were selected by the investigator using simple random sampling technique.

\section{HYPOTHESIS: 1}

There will be a difference in the level of emotional intelligence and achievement in zoology among higher secondary students.

Table 1: Frequency and percentage difference in the level of emotional intelligence and achievement in zoology among higher secondary students.

\begin{tabular}{|l|c|l|l|l|l|l|l|l|l|}
\hline \multirow{2}{*}{ NAME OF THE VARIABLES } & \multicolumn{3}{|c|}{ LOW } & \multicolumn{3}{|c|}{ MODERATE } & \multicolumn{3}{c|}{ HIGH } \\
\cline { 2 - 10 } & Q1 & F & $\%$ & Q2 & F & $\%$ & Q3 & F & $\%$ \\
\hline $\begin{array}{l}\text { EMOTIONAL } \\
\text { INTELLIGENCE }\end{array}$ & 118 & 75 & $25 \%$ & 132 & 131 & $43.66 \%$ & 140 & 94 & $31.33 \%$ \\
\hline $\begin{array}{l}\text { ACDEMIC ACCHIEVEMENT IN } \\
\text { ZOOLOGY }\end{array}$ & 61 & 80 & $26.66 \%$ & 76 & 138 & $46 \%$ & 85 & 82 & $27.33 \%$ \\
\hline
\end{tabular}

Table1 According to the table totally $25 . \%$ of higher secondary student belong to low level of emotional intelligence, $43.66 \%$ of higher secondary students belong to moderate level of emotional intelligence, $31.33 \%$ of higher secondary students belong to high level of emotional intelligence.

According to the table totally $26.66 \%$ of the selected higher secondary students belong to low level of Academic Achievement in zoology, $46 \%$ of the selected higher secondary students belong to moderate level of Academic Achievement in zoology, and $27.33 \%$ of the selected higher secondary students belong to high level of Academic Achievement in zoology. 
So the hypothesis No: 1 is accepted. Thus it is inferred that there is a difference in the level of emotional intelligence and achievement in zoology among higher secondary students.

\section{HYPOTHESIS: 2}

There will be a significant mean score difference in emotional intelligence between the group based on sex among higher secondary students.

Table 2: Means score difference and t-test of emotional intelligence between the group based on sex among higher secondary students.

\begin{tabular}{|c|c|c|c|c|c|c|c|c|}
\hline S.NO & GENDER & $\mathbf{N}$ & Mean & S.D & df & t-value & p-value & Result \\
\hline 1. & BOYS & 32 & 121.41 & 10.220 & \multirow{3}{*}{300} & \multirow{3}{*}{-4.086} & \multirow{3}{*}{.006} & \multirow{3}{*}{ S } \\
\hline 2. & GIRLS & 267 & \multirow{2}{*}{131.70} & \multirow{2}{*}{13.796} & & & & \\
\hline 3. & TOTAL & 300 & & & & & & \\
\hline
\end{tabular}

The Table 2 shows that mean score difference in emotional intelligence between the group based on sex among higher secondary students. The calculated t-value is statistically significant at 0.05 levels and hence, the hypothesis 2 is accepted. It can be concluded that there is a significant difference in emotional intelligence between the group based on sex among higher secondary students.

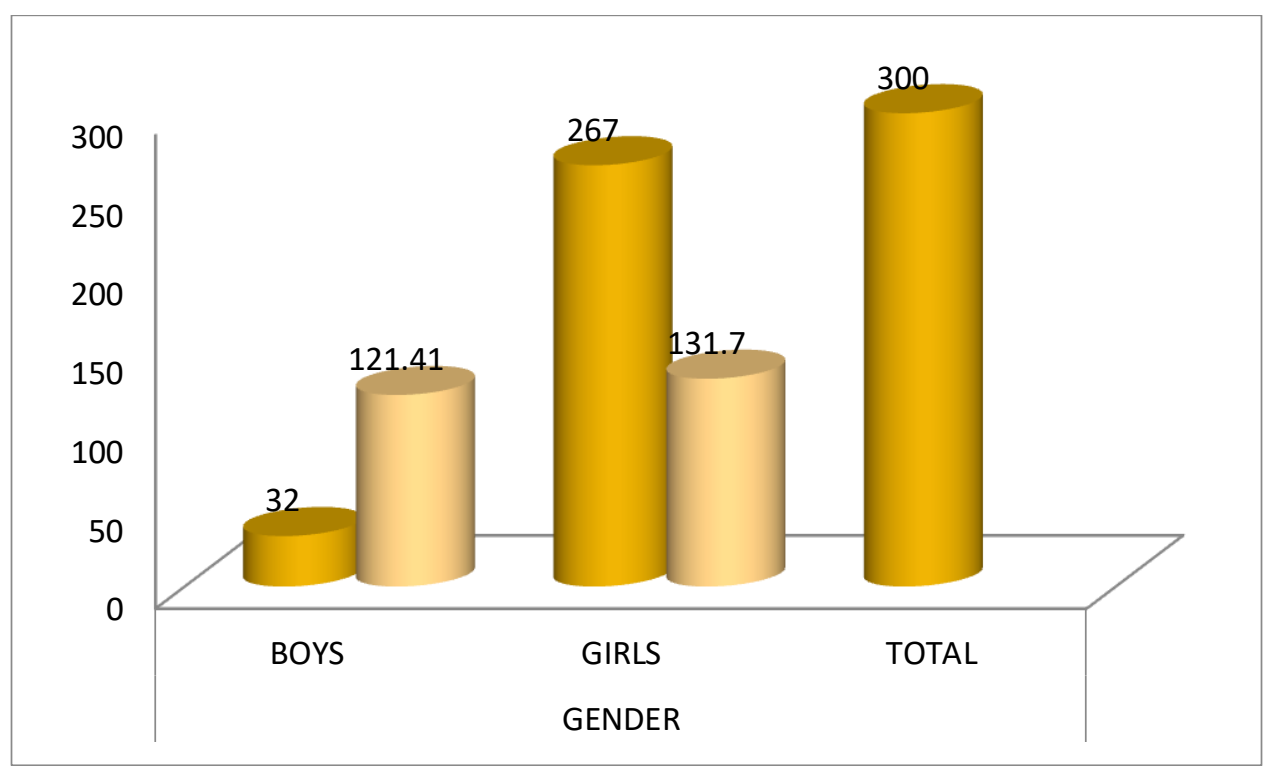

Chart 1: Mean Score Difference in Emotional Intelligence between the Group Based on Sex among Higher Secondary Students

\section{HYPOTHESIS: 3}

There will be a significant relationship between emotional intelligence and its impact on achievement in zoology among higher secondary students. 
Table 3: Relationships between the emotional intelligence and its impact on achievement in zoology among higher secondary students.

\begin{tabular}{|l|l|l|l|l|}
\hline VARIABLES & $\mathbf{N}$ & 'r' value & 'p' Value & Result \\
\hline $\begin{array}{l}\text { EMOTIONAL } \\
\text { INTELLIGENCE }\end{array}$ & 300 & & & \\
\cline { 1 - 2 } & & & .000 & $\mathrm{~S}$ \\
$\begin{array}{l}\text { ACHIEVEMENT } \\
\text { IN ZOOLOGY }\end{array}$ & 300 & & & \\
\hline
\end{tabular}

The table 3 shows the relation between the emotional intelligence and its impact on achievement in zoology among higher secondary students. According to this table the correlation value (.000) in emotional intelligence and it impact on achievement in zoology is statistically significant at the 0.01 level. Hence this hypothesis 8 is accepted and it can be concluded that there is a positive correlation between emotional intelligence and its impact on achievement in zoology among higher secondary students.

\section{Conclusion}

The findings reveal that totally $25 . \%$ of higher secondary student belong to low level of emotional intelligence, $43.66 \%$ of higher secondary students belong to moderate level of emotional intelligence, $31.33 \%$ of higher secondary students belong to high level of emotional intelligence. $26.66 \%$ of the selected higher secondary students belong to low level of Academic Achievement in zoology, $46 \%$ of the selected higher secondary students belong to moderate level of Academic Achievement in zoology, and $27.33 \%$ of the selected higher secondary students belong to high level of Academic Achievement in zoology. There is a significant mean score difference in emotional intelligence between the group based on sex among higher secondary students. There is a positive correlation between emotional intelligence and its impact on achievement in zoology among higher secondary students.

\section{Reference}

[1] Gardner, H. (1983/1993). Frames of Mind: The Theory of Multiple

[2] Golden, S. A. R. (2011). Problems and Prospectus of Distance Education. Quality Enhancement In Distance Education For Life Long Learning, 1(1), 343-344.

[3] Golden, S. A. R. (2017). Attitude of Students and Teachers towards E- Learning - An Analysis. Recent Research in Social Science \& Humanities, 1, 5-10.

[4] Golden, S. A. R. (2017). Attitude of Students and Teachers towards E- Learning - An Analysis. Recent Research in Social Science \& Humanities, 1, 5-10.

[5] Golden, S. A. R. (2017). Recent Research In Social Science \& Humanities.

[6] Intelligences (10th Anniversary Edition). New York: Basic Books.

[7] Mayer, J. D., \& Salovey, P. (1997). What is emotional intelligence? In P. Salovey \& D. J. Sluyter (Eds.), Emotional Development and Emotional Intelligence: Educational Implications (pp. 3-34). New York, NY: Basic Books, Inc.

[8] Mayer, J. D., Caruso, D. R., \& Salovey, P. (2000). Selecting a measure of emotional intelligence: The case for abil-ity scales. In R. Bar-On \& J. D. A. Parker (Eds.), The Handbook of Emotional Intelligence: Theory, Development, Assessment, and Application at Home, School, and in the Workplace (pp. 320-342). San Francisco, CA: Jossey-Bass. 
[9] Petrides, Norah Frederikson and Adrian Furham, 2004, The role of trait emotional intelligence in academic performance and deviant behavior at school, Publication: Personality and Individual Differences, v36 n2 (200401): 277-293

[10] Regi, S. B. (2016). Prospectus \& Challenges Of Women Entrepreneurs-A Study With Special Reference To Tirunelveli District. International Journal Of Scientific Research And Modern Education, 786, 792.

[11] Salovey, P., \& Mayer, J.D. (1993).The intelligence of Emotion. Intelligence, 17, 433 -442.

[12] Salovey, P.,\& Birnbaum, D. (1989). Influence of mood on health-relevant cognitions. Journal of Personality and Social Psychology, 57, 539-551.

[13] Salovey.P. \& Mayer J.D. (1990). Emotional Intelligence, Imagination. Cognition and Personality, $9,185-211$ 